\title{
FASHION, AFFECT, AND POETRY IN A GLOBAL CITY
}

\author{
Winnie L. M. YEE \\ University of Hong Kong
}

\begin{abstract}
Everyday life is a central theme of Hong Kong poetry. Many Hong Kong poets use the quotidian as a starting point for the exploration of history and alternative imaginings. This mundane focus, unlike the colonial dreamscape of Hong Kong as an economic miracle, allows writers to reflect upon Hong Kong as a post-colonial and global space. The Hong Kong writer Natalia Chan examines the complex nature of everyday life within the space of the global and post-colonial city. Chan's poems deal with the essence of everydayness and use commodities to conjure up the vivacity of the urbanscape of Hong Kong. Unlike the political and economic discourse that is usually used to define Hong Kong, Chan's work portrays Hong Kong as a city that offers the possibility of daily re-creation against the background of history. In this article, we will examine Chan's use of the circulation of commodities in the global world and explore the way fashion becomes a point where high and popular culture, private and public domains, and local and global interests clash, negotiate, and fertilize each other. Chan's works do not conform to the economic and prosperity discourse that has repressed Hong Kong; rather, she guides her readers to re-experience the everydayness of routines, to celebrate alternate ways of understanding the urbanscape, and to open themselves to the potentialities of art and the everyday.
\end{abstract}

\section{Introduction}

Everyday life is a central theme of Hong Kong poetry. Many Hong Kong poets use the quotidian as a starting point for the exploration of history and alternative imaginings. Since the 1970s, Hong Kong writers 
have explored the specificities of local culture by looking at an ordinary day. This mundane focus, unlike the colonial dreamscape of Hong Kong as an economic miracle, allows writers to reflect upon Hong Kong as a post-colonial and global city.

This idea of everyday life, however, is written against a backdrop of danger and anxiety. Since the signing of the Sino-British Joint Declaration between Britain and the People's Republic of China (hereafter PRC), Hong Kong has remained under the cloud of a generalized anxiety, caught in a perpetual act of ending (its official colonial history), transition (from former colony to Special Administrative Region), and return (to the motherland). The development of Hong Kong from a fishing village to a modern city has rendered it a unique space that cannot be easily subsumed in the national discourse (Chan 1995, 3). Though Hong Kong is often marginalized and its culture dismissed, its unique situation has been cherished by many well-established poets such as Ping-kwan Leung (梁秉鈞), Yip Fai (葉輝), and Natalia Siu-hung Chan (陳少紅). They recuperate the space of everyday life to illuminate Hong Kong's unusual culture and its complex relationship with both Chinese and Western culture.

The space of everyday life, to these poets, is double-coded. Its routines have become an "historical optic" through which the larger history can be registered. In the case of Hong Kong, this historical optic allows us to understand the city apart from its metropolitan outlook and developmental grand narrative, and to see how memories, emotions, and locales are interwoven and shaped by history. Reciprocally, the poetics of everyday life urge a transvaluation where reality can be critiqued and its values judged.

The Hong Kong writer Natalia Chan, better known by her pen names Luo Feng and Lok Fung (洛楓), explores the dislocations caused by border-crossing, colonialism, globalization, and disruptive socio-political changes. Chan examines the complex nature of everyday life within the space of the global and post-colonial city. To date, she has published three volumes of poetry, Distance (距離 1988), Missed Encounter (錯失1997), and the award-winning The Flying Coffin (飛天棺材2007). As winner of the prestigious Biannual Hong Kong Literary Prize in 2007, The Flying Coffin has attracted a great deal of critical attention in the local literary community. Scholars and critics observe that Chan is able to navigate 
freely between the classic and the popular and between logic and emotion to establish her own unique poetic style. The Flying Coffin consists of five sections: "Romantic Network," "Deconstructing Romance," "A Skier's Discourse," "City: Life and Death," and "California Dreaming." The 52 poems, written over the course of more than a decade, explore the nature of love and gender in the context of everyday life. With a remarkable sense of humour and keen observation, she "translates" the mundane quality of everyday life into vivid alternative images. By breaking down the dichotomies between high and popular culture, male and female perspectives, the private and the public, and the local and the global, she presents the various competing voices of women immersed in the tensions of everyday life. Chan encourages the reader to use everyday occurrences as a means of reflecting on the pressing problems of Hong Kong and other global cities.

The quotidian in Flying Coffin is framed by historical moments, the moments often understood to be the critical moments in Hong Kong's history between 1997 and 2003. For most citizens of Hong Kong, these events were critical because of their magnitude, their scope, and their destructiveness. From Hong Kong's official reunification with the motherland in 1997 to the Asian economic crisis and the outbreak of severe acute respiratory syndrome (SARS) in 2003, the disillusionment of the Hong Kong people has deepened: their high hopes for political independence and economic prosperity have been dashed. These historical events have heightened the self-awareness of Hong Kong citizens: they have been required to examine their identity in a national and global context, and to readjust their expectations for the future. Chan has described Hong Kong as a city "on the edge of time," even after the 1997 handover. The Hong Kong people have had to find a way of dealing with the effects of globalization and to come to terms with the new relationship with the motherland. They remain at the margins in order "to keep a critical distance, to be indifferent, and avoid being indulged in or obsessed by the illusory glamour of the city" (Chan 2002, 3). Chan refrains from describing critical events directly; rather, she observes the mundane activities that register their impact. To show how Chan reveals the resonance of the everyday, this paper will mainly focus on five poems from Flying Coffin, written between 1998 and 2004. 
In his analysis of everydayness in Japan, Harootunian reflects on Western modernity and its transvaluation in the Asian context. He maintains that the boredom and routine of a capitalist lifestyle cannot suppress the potential of the everyday. Instead, the materiality of the everyday "was called to stand in as the microcosm for the macrocosmic everyday world" (Harootunian 2000, 89). To Walter Benjamin, the microcosm of the everyday challenges the progressive, repetitive, and linear time that defines modernity. It shows "the everyday world as alienation brought on by routine yet still filled with possibility, the difference in the same" (Harootunian 2000, 107). The everyday could well be the site of "profane illumination." Chan's poems similarly focus on material conditions, though she does not take the clichéd view of Hong Kong as the product of economic success. Instead, she sees in the city's economic activities an encapsulation of its liveliness and its colonial history, which can be transformative. The world of commodities is not necessarily evil and oppressive: it can be perceived as the site where the essence of Hong Kong-its vibrancy and agencycan best be appreciated. Fashion, from this point of view, is the transitory reflection of the material world that is often condemned as perpetuating unfulfilled desire. Chan sees fashion as a phenomenon that links affect, objects, body, and the city, and encourages a larger historical perspective. She not only elevates fashion's lowly status but also relocates poetry as a means of challenging the grand narrative. In her works, fashion, commodities, and everydayness "serve as a historical optic to widen our understanding of the processes of modernity” (Harootunian 2000, 4).

Chan's poems deal with the essence of everydayness and use commodities to conjure up the vivacity of the urbanscape of Hong Kong. The commodities depicted in Chan's works represent much more than mere consumer products. Unlike the political and economic discourse that is usually used to define Hong Kong, Chan's work portrays Hong Kong as a city that offers the possibility of daily re-creation against the background of history. In the following sections, we will show how Chan's work deviates from the dominant discourse of Hong Kong story and will examine her use of the circulation of commodities in a global economy. Finally, we will explore the way fashion becomes a point where high and popular culture, private and public domains, and local and global interests clash, negotiate, and cross-fertilize. Chan's works do not conform to the 
economic and prosperity discourse that has repressed Hong Kong; rather, she guides her readers to re-experience the everydayness of routines, to celebrate alternate ways of understanding the urbanscape, and to open themselves to the potentialities of art and the everyday.

\section{Poetry as Minor Tale: A Gendered Perspective}

What strikes readers of Chan and what distinguishes her from other equally renowned Hong Kong poets such as Ping-kwan Leung or Waitong Liu (廖偉棠) who share her concern with the quotidian is her preference for the "minor mode." "Minor," in its original musical sense, refers to the interval "less by a semitone than the equivalent major interval" (Oxford Dictionary). "Minor," in the case of Chan, refers to her intention to refrain from directly portraying major critical events in her poems. Her focus is on the "semitone," the tone that often evokes sadness and pensiveness. Rather than making judgements on the place where she grew up, her poems challenge fixed ideas and ideologies about the way the urban space of Hong Kong should be understood. Her lack of a grand narrative and her focus on affect and feelings are both suggestive of the minor mode. Minor tales are critical because they are in danger of being overlooked. In Chan's poems, the persona's relation to the city is close to that of the flâneur as described by Baudelaire. By dwelling on the routines of the urban residents - their commutes on public transport, their trips to the mall - Chan presents the mundane with a kind of freshness. Like the flaneur's wanderings, the experiences depicted in her poems must be understood as "part of a politics of strolling which relate these experiences with the cultural apparatus" (Patezold 2000, 216). While Chan shares with her contemporaries an interest in the fresh and new, her personae do not cut themselves off from the past. For Chan, a new and fresh perspective can only be generated from a conscious reflection on Hong Kong's colonial history and a refusal to accept the dominant discourse. A gendered point of view, one that focuses on the minor, would enable such a nuanced perspective.

Feelings and emotions are often categorized as personal, subjective, and unimportant; their fate is to be marginalized, neglected, and buried. 
Minor tales are critical because they escape rationalization and resist categorization. Feelings and sentiments are fragmented and incoherent. The fact that they are not easy to understand or to rationalize is what makes them attractive to Chan. The urban space of Hong Kong similarly cannot be coherently presented or represented, and Chan refuses to impose a coherent pattern. The fragmented feelings in a minor tale accurately represent the condition of Hong Kong. Our neglected feelings and memories must come to the forefront because they provide us with our picture of, and affection for, the city. The five sections of Flying Coffin return to the themes of love, relationships, Hong Kong's future, and the alienated sense of being away from home. Chan presents, in this unique way, the multiple and heterogeneous perspectives that define a city. She looks at the way commodities produced gendered sentiments and reflect the physical existence of Hong Kong's urbanscape. For example, in "In My Days of Whitening," the persona refrains from meeting people because of her skin-whitening treatment. At the surface level, skin-whitening products are agents of women's beautification, yet the poem appropriates them as a means of marking the passage of time:

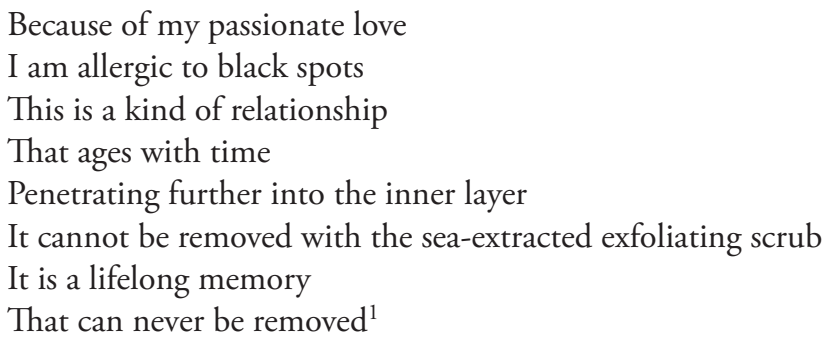

The passionate quest for beauty may represent a stereotypical gendered view, but the poem is about more than the function of commodities. Black spots are used as metaphors for the dark periods of life; the lament for days gone by stresses the contrast between the surface level (both the surface of the skin and the surface level of the poem) and the latent (the consciousness of time passing). People in the city interact with commodities on a daily basis, but for Chan the material satisfaction is less significant than the sentiments the commodity can inspire. Rey Chow 
observes that Hong Kong's accomplishments are often viewed as a sign of "deficiency, degeneracy, abnormality, and hence basic inferiority" (1993) and, therefore, do not provide us with any thoughtful or instructive understanding of the city. The re-enchantment of commodities is celebrated by Chan. Rather than treating them as trivial, gendered, or compensatory, Chan uses the commodities to make a space that symbolizes the city at the present moment.

"Minor" works (those by authors marginalized in their homelands) can have political and collective importance. ${ }^{2}$ The writing of minor tale in the form of poetry is itself political. The decision to use poetry as the platform to unravel the complex relation between the personal and the collective is a challenge to the common discourse, like the challenge offered by the petit récits à la Lyotard to the grand narrative. Chan writes about beauty products in "In My Days of Whitening" and "The Hairstraightening Lover," about fashion in "Fashioning Passion" and "The Lover, My Clothes," and about public transit in "The Railway Affectivity." These ordinary subjects always trigger a more philosophical reflection on the condition of the city. The alternate way of reading Hong Kong defamiliarizes the urbanscape. Chan's poems are all minor tales that attempt to reveal the complexity of the city and suggest that a gendered perspective has a particular resonance. Patezold's observes that "[ $t]$ he rapidly changing urban scenes require a flexibility and openness with regard to the readings and rereadings of the symbolic meanings embodied in the urban space" (2000, 218-219). Like the flâneur strolling around the markets and historical markers, Chan's works lead to an awareness of new images and new readings of the contemporary culture. In Chan's case, poetry serves as a creative space of resistance that plays at the borders between high and low culture and between the sentimental and the political. Such border skirmishes challenge the common sense and the dominant ("major") view.

\section{The Profane Illumination of Fashion and Affective Bodies}

While Deleuze and Guattari discuss the political significance of "minor literature," Bennett's examination of "minor tales" focuses on the 
enchantment of objects and the attachment to the non-human. Bennett maintains that the disillusionment of the Enlightenment led to a tendency to cut off any affection for the world $(2001,4-5)$. She calls our attention to the minor tales of the people, the "alter-tale" of the everyday that allows the world to be "re-enchanted." Chan's poems reflect this view, but they extend Bennett's scope to include not only objects but also the urban space and the human body, particularly the female body.

Dress and fashion always have a specific temporal and social place. Entwistle sees dress as "the visible form of our intention" and maintains that the body "is not merely a textual entity produced by discursive practices but is the active and perceptive vehicle of being" $(2015,29)$. Following this line of thought, fashion and its representation is both a means of attending to one's body and also an act of actualizing a dialectic between body and self. Chan's attention to fashion in her poetry highlights the interaction between bodily experience and personal perception.

In "Fashioning Passion," the range of clothes in the boutique do not simply lure fashionistas to indulge their appetite for novelties but also create a space where the self is formed. The juxtaposition of internal and external space suggests a temporal collage of the cultural condition of Hong Kong, linking the personal with the urban:

This beloved boutique acts as a city in its unsettled climate Where one seeks solace in one's own indulgence

At the outset of the poem, the persona is inside the boutique, but her thoughts transcend its limited space, encompass the larger urban space, and indulge in the sense of hovering in between. The poem zooms from interior to exterior: "The smog buildup/ Casts a veiled vision over Victoria Harbor." The unclear path of the city (and its future) is symbolized by the smog. Similarly, "The black cat cloaked with a layer of gray dust" is connected to the persona "Wrapped in the checkered scarf." This shift from inner space to an imagined urbanscape and back to personal feelings conveys the lived experience of consumption. If fashion can reflect a perception of the city, Chan's poems indicate the indestructible connection between the circulation of commodities and the destiny of the city. The poem continues, 
In the nostalgia for trend retro, we realize

No fashion could be outdated

This references to fashion cycles highlights the commodification of our memories. Hong Kong is considered a place of rampant consumerism. Fashion is ever new and ever same. It is exciting and alluring, but it can exert a numbing influence that deadens our initiative to challenge post-colonial conditions. Chan's poems refuse to conform to or simply recycle a clichéd picture of Hong Kong:

But our act of forgetting only amplifies the awareness

Caught between the dolman sleeve and the A-line skirt

We can only accede that our complexion be, as fated,

Folded, flattened into strips or grids

For clothes are to be worn and

Nowhere else to be

Clothes become not merely commodities that encourage consumption but a reminder of one's agency in making conscious choices. The intention to create an individual fashion style underscores the conscious mind of the persona. She refuses to be stigmatized as shopaholic, who consumes for the sake of consumption; instead, she uses fashion trends as an emblem of a rejection of forgetting. To remember fashion cycles and individual characteristics can be perceived as an attempt to highlight one's responsibility not to be numbed by the commodification of the city. Consumers are not necessarily passive. To be aware of differences is a conscious act of an individual agent that combats forgetting. Chan's poems about fashion allow her to repaint the city, to re-imagine the urbanscape through constant negotiation between the mundane and the creative.

Bennett values the minor because it calls attention to the "magical sites [that are] already here" $(2001,8)$. Although Bennett does not state clearly what magic these sites possess, her notion blurs the dichotomy of enchantment and disenchantment. The magical sites in Chan's poetry are the sites of affect, feelings, and emotions that are created by circumstances and that shape the condition of our urban space. While Chan focuses on the mundane aspects of everyday life and the popular culture 
version of glamour, she also looks at the way memories and identity are shaped by these cultural narratives, which are often considered unimportant. In "The Lover, My Clothes" (translation by Wayne Yeung), the notion of fashion is again appropriated to conjure up a city that is both progressive and cyclical. The forces of both backward-looking nostalgia and forward-looking consumerism, characteristic of post-colonial Hong Kong, co-exist in the poem. The destiny of the city is reimagined in surreal temporalities: "What if there're two summer seasons." It is as if the persona is asking whether the summer the city was born (July 1, 1997, was the date of the establishment of Hong Kong as PRC's Special Administrative Region), with its disputes and internal turmoil, can be reworked:
What if there're two summer seasons
So that the fixed deposit of love has a longer maturity
What if lovers are just my clothes
So that I can change the way I miss them like the latest fashion

The poem starts with a strong thirst for stability and sustainability (the "fixed deposit"), which is immediately pulled back by the force of swift changes in fashion. This dichotomy reflects the dilemmas that have trapped Hong Kong people. Hong Kong can be viewed as a gendered body that has to be dressed up by different imaginations, especially a consumerist imagination:

Your mind is obscure behind the see-through chiffon dress

While my tassels on the jean become a burdening mess

No paisley prints blow away the green ending of a relationship

The folk embroidered weaves an ageless story too good to be true

The revelation of the persona is mythical, but is quickly demystified by the following lines: "Clothes and people, once in, now out, / Drag on a shadow from this year that/ Won't get you admitted to the next fashion show." Dwelling in the present is impossible for a city that is premised on, and celebrated for, its speed. The moment now becomes a prosaic instant that captures the flow of the city's fashion industry, a cacophony 
of disputes that define the current condition of the city, and a personal reflection of an urbanscape produced by metropolitanism. The awakening promised in Chan's poetry is one that de-alienates the city and portrays it as vibrantly interacting with numerous internal and global forces. For Chan, there is never a shortage of opportunities for self-reflection. In this case, the revelation of potentialities and opportunities are already embedded in the repetitive everyday world. This echoes Benjamin's "profane illumination" $(1978,179)$, a concept that he used to describe the materialist inspiration of the Surrealists' experience of Parisian urban everyday life and its new object world (Gordon 1997, 204). In Chan's case, the profane illumination can also be applied to the case of post-modern Hong Kong, where the self-imposed consumerism can be challenged and re-imagined in poetry. The emotions become a lens through which the larger historical picture can be registered and witnessed. Rather than focusing on the "critical moments," she portrays the way the mundane can become a magical site, invoking both joy and disappointment, and shaping the world in which we live.

The portrayal of the city is further mediated by the stress on affect in Chan's poetry. In his introduction to Deleuze and Guattari's $A$ Thousand Plateaus, Massumi argues that affect is beyond personal feeling. He distinguishes among feelings, which are personal and biographical (links to history and experience), emotions, which are social, and affects, which are "prepersonal" (1987, xvi). The notion of the prepersonal requires some explanation: it is a moment of unformed and unstructured potential. It is the body's way of preparing itself for action in a given circumstance by adding a quantitative dimension of intensity to the quality of an experience (1987, xvii). Chan's poems support Massumi's view in her choice of subject matter and in her use of language. Readers would agree that the subject matter of Chan's works shows an extraordinary range-from technological gadgets (computers, cyberspace, TV sets), popular culture (TV drama, film, music), pets (cats and lizards), to philosophical meandering (life and death, relationships, the city). This collage conveys an "unformed and unstructured potential" that encourages a different sensibility and hence a new reading of the urban life. In terms of language, her poems open up a creative space that refuses to be categorized easily. She plays with language and form, putting advertising slogans, slang, and 
classical Chinese into the mix. These juxtapositions produce various effects (and affects), which compel readers to re-read her works. The complexity of feelings evoked by her works represents the many-sidedness of the urban space of Hong Kong. This many-sidedness is also evident in her depiction of different districts of Hong Kong: Tsim Sha Tsui (a popular tourist spot), Mongkok (frequented by local shoppers), Central (downtown business district). By describing the range of activities that take place in these districts and the various sentiments associated with people who frequent them (travellers in Tsim Sha Tsui, locals in Mongkok, expatriates in Central), Chan is suggesting that the city and people of Hong Kong are diverse and cannot be pinned down easily.

Another feature of affect that can be noted in Chan's poetry is the dynamic shift between "being affected" and "affecting" that occurs in the relationship of the persona and the object described. One significant feature of affect is its two-way interaction. When you affect something, you are at the same time opening yourself up to being affected. This dynamic of exchanges and interactions is illustrated by the affection for objects. The objects described in Chan's works, including clothing, technologies, and commercial products, are numerous and diversified. In "The Lover, My Clothes," the weather, the persona's outfit, and the events in the city are all interconnected and mutually affecting: "March mist with spring rain, putting / A bohemian embroidered blouse on me, / Weaves two separate cities with the thread of my cuff." The two cities could be the real one and the imaginary one. The image may also have a political edge. The narrator may be referring to the connection between Hong Kong and its motherland: no matter how different their political and economic systems are, history has linked them together, just as textiles are woven together. And again, this reminds us that the poem's intention to re-enchant mundane objects and link them to the larger destiny of the city.

Chan's poems focus on the continued interactions between the human and the inhuman and the energy that is generated by these dialogues. The instrumentality of objects is not the issue in her poetic world. Rather we see the complex web of relationships wherein consumers and goods are shaped by each other, and the inhuman becomes a constant reflection of one's identity. It is also important to note that the magical sites of commodity do not bring merely awe, joy, and wonder but also 
incite fear and a sense of uncanny: there are many references to coffins, death, and cemeteries in her descriptions of the cityscape.

\section{Between Local and Global: The Historical Optic of the Everyday}

Another feature of affect is that it often emerges during a moment of transition. Transition in this context can refer to circulations, flows, transmissions, or contagions. Transition characterizes the urban space of Hong Kong. Times of change inspire strong feelings and open up areas of energy and potential. This is most vividly registered in Chan's depiction of the urbanscape. In a number of her poems, she turns urban districts like Mongkok, Central, or Tsim Sha Tsui into characters in order to explore their affect. In "Poetic Entry on Mongkok," the stores selling computer gadgets and pirated copies of films are used to evoke a critical and gendered imagination of the city:

\section{I return from the Long Vacation of Love Generation ${ }^{3}$}

Bringing the film reels of memory in reverse time-space

And seeking the possibilities tantamount to the characters and plots You're on my mind ${ }^{4}$

The references to Japanese soap operas and their English titles suggest what Giddens calls a "global reflexivity" at both the linguistic and conceptual levels. The dominant feature that characterizes globalization, according to Giddens, is people's ability to orientate themselves to the world as a whole as both "locals" and "cosmopolitans." Cheung argues that in Chan's poems, the "reproduction of the global in the local is found in moments of daily consumption and appropriation of foreign commodities and cultures" (2012b, 9). The constant incorporation of popular culture and foreign elements in works of Chan highlights the cosmopolitanism of the poet as well as the city that she writes about.

For a poet who uses fashion and commodities to reflect on life in the city, a logical setting would be the shopping mall. Shopping malls can be viewed as repressive institutions where identical mass-produced commodities incite desires and fantasies. They can also, however, be viewed 
as places that allow people to traverse various cultures and traditions. In "Traversing between the New Year's Eve and the New Year's Day in 2003" (translation by Esther Cheung), the new year is crystallized in the acclaimed shopping paradise-Hong Kong. The phantasmagoric images of globalization and consumer society appear in miniature form in the shopping mall:

A polar bear shakes its head on a man-made snow scene

Announcing the possibility of the revival of a dead city

One day in the middle of the shopping mall

An imposing Christmas tree reaches the fourth floor

Its green plastic or silky leaves

Are perfect matches with the glittering, white crystals

The celebration of the Western tradition, New Year, is undercut by the poem's caustic observations. The dichotomy between the nature represented and its artificiality, between the liveliness of the shopping mall crowd and the dead city further conveys the poem's revelation of disillusionment in a prosperous city.

Seeing the intertwined branches and twinkles under the spotlight

She starts to believe

She has already been free from the tragic fate of an ugly duckling

Transformed into a swan

Desiring flight

But the illusory lights weigh her down

All the way to the far end of the staircase

The critique of the false promises of capitalism and its fabricated desires is vividly evoked. Rather than dwelling on the evidence of economic success embodied in the circulation of commodities in the shopping mall, the narrator calls for a new beginning. This new beginning is not just the persona's but Hong Kong's as well. It is time to get beyond the false promises that have lingered since the colonial past: "She has put on her overcoat again / Allowing time to be thinner than her clothing / Allowing her apparel to outlive time." The reference to outliving time suggests the 
persona's willingness to think ahead to new possibilities, to have a pair of fresh eyes for the New Year. The poem also hints at a moment of crisis for the city. Benjamin's discussion of the necessity to subject the modern world to scrutiny is a useful reference point here. He maintains that " $[\mathrm{h}]$ istorical materialism wishes to retain the image of the past which unexpectedly appears to man singled out by history at a moment of danger" $(1968,255)$. To articulate this moment of danger, especially in the fluid city, artistic responses and creative works of reflection must be timely and immanent. In classical Greek tragedy, the resolution of a crisis is not fated but depends on the characters' actions and personalities. Individual agency is required to make changes in society: "It is clear that crisis in this sense requires the subject to exercise its capacity of making judgement by evaluating and reflecting upon past and present experience" (Cheung 2004, 249). Given that Chan presents the struggle at the transition between the past and the future, the present becomes the moment when reflection and evaluation must take place.

What links these temporalities together is the emphasis on circulation among people and things - the mutations of the city. The changes in a city are not reflected in the historical events that are considered critical moments but in the continual mundane changes to the living space. As shown in "Traversing between the New Year's Eve and the New Year's Day in 2003," we are affected and the city is imagined through these mundane changes. The changes in space and in our life are best understood through our feelings and affect. The uniqueness of affect is the passage from one state to another: it is an intensity characterized by an increase or decrease in power. In Chan's poems, this intensity is registered in three mutations: the mutations in the city, in the poet's feelings towards the city, and in the constructed relation between the city and history. The changes in state create a chain reaction leading to a new convergence of feelings, body, and external stimuli. This convergence, in turn, influences the individual's capacity to act in the world. It is hinted that the stronger the intensity of the convergence, the stronger the resultant capacity to reshape the world. In a way, the affect provides the poet with the power to engage in the social dialogue. This is in keeping with the notion of "minor" - the individual (or the affect) is always social and political. 


\section{Conclusion: Art as Praxis and Poiesis}

In the preface to The Flying Coffin, Chan comments on her debt to Hélène Cixous. She reiterates Cixous's idea of writing — as both natural and necessary. Writing is a way for Cixous to fight against illness, silence, and discrimination based on race, language, and gender. Chan notes it is not that Cixous chose writing in her life, but the reverse (Chan 2007, xxxvii). Chan also finds in poetry a tool that allows her to get close to death, fear, and loneliness in the city. Through writing about death, the poet is allowed to be reborn and to look at the world with a pair of fresh eyes. This also explains why Chan continually challenges herself by dealing in an ever-increasing range of subject matter. It is only through these shifting perspectives and positions that readers will be able to understand the city differently.

To conclude, Chan's focus on fashion can be perceived as a kind of mnemonic act reminiscent of Western writers such as Baudelaire: "It is through such a dialectic of the empirical and the utopian that alienation can be disarticulated" (Cheung 2012a, 82). Chan's poems can be interpreted as possessing a similar magical power: her poetry reconfigures the everyday, both particular and general. What Chan has demonstrated in her poetry is a constant focus on the trivial, the mundane, and the affective- those aspects of life that fail to capture the attention of historians. Her fresh perspective penetrates the microhistory that defines the cityscape of Hong Kong. The lived experience that conjures up the city is better illuminated through microcosms than macrocosms. Her works are not simply reflections but critical negotiations of the local and global. As Cheung points out, Chan's urban poems deal with the dialectic between suppression and reflection, public and private: "Chan's local placewriting has become a means to produce a worlding process where the historically placed places are now cast as points of critiques of life in a global city" (2012b, 5). Chan's poems succinctly deploy the everyday to critique the post-colonial condition of Hong Kong and the state of the world. Fashion and commodities closely link gender to the body. They also provide worldviews based on the process of consumption. Still art can use fashion and commodities to register enchanted moments when everyday objects convey the uniqueness of Hong Kong. Chan succeeds 
in revealing anew the importance of the everyday and re-imagining the potentialities buried in the longue durée of commodification.

\section{Acknowledgements}

This work was fully supported by a grant from the Louis Cha Fund (Chinese Studies) at the University of Hong Kong. Thank you to the editors and anonymous reviews at ESP for their valuable comments on earlier versions of this article. 


\section{In My Days of Whitening}

In my days of whitening

I refused visitors

Afraid of light

I failed to face the glint on my friends' lenses

The sympathy and consideration

Though warm

Kill all rejuvenating cells

Because of my passionate love

I am allergic to black spots

This is a kind of relationship

That ages with time

Penetrating further into the inner layer

It cannot be removed with the sea-extracted exfoliating scrub

It is a lifelong memory

That can never be removed

SKII has a new mask that can render your face as fine and smooth as eggs The dark pigments would be lightened in twenty-four hours

Use it for twenty-eight days straight

With wholehearted trust and patience

You always carry an aging weary face

On your rambling returns

Unfortunately I am allergic to eggs

And have no particular sensitivity to the causal dilemma between the chicken or the egg

And fail to clarify

Whether we should fall in love and then break up

Or the other way round

Hence decided to have both processes

Run parallel

Obviously

I have no intention to treat you as 
Incurable suffocating pores or blackheads

Because deep cleansing and whitening

Would bring inevitable pain

I can only cut off my thoughts for you

Under the condition that my skin does not have to be fully cured

In my days of whitening

I am an inch taller, two kilograms heavier

Insomnia, anorexia, and fatigue no more

The skin is hydrated

Looking back grateful to love myself

Could reduce wrinkles and blemishes

Let sunshine bring with it the chirping of the bird

1. 2.2015

\section{我在美白的日子}

我在美白的日子

謝絕探訪

因為怕光

便不能應付朋友閃亮的鏡片

那同情和諒解

自以為灼熱

其實最會殺死正在更生的細胞

最近由於戀愛

所以患上了黑斑過敏症

那是一種會隨年月

而衰老的情愛

而且深入皮膚的內層 
任算天然海底植物提煉的磨砂 也磨不掉的 一生的印記

聽說SKII有剝殼雞蛋的面膜

可以二十四小時再生暗啞的傷口 祇要循環使用二十八天

一心一意的信任和等候

你總會帶著在外面因遊蕩

而老去的容顏回來

可是我天生對雞蛋敏感

而且無法釋懷雞與蛋先後的次序

終於也搞不清楚應該

跟你相戀然後分手還是

先分手才再相戀

於是最後決定這兩個護膚程序

同一時間進行

\section{當然}

我並不想真的

把你看成無藥可救的黑頭或粉刺

因為深層的潔淨和漂白

會帶來切膚之痛

但在不能換臉的情勢下

祇好戒掉對你的念念不忘

我在美白的日子

長高了一英寸 長㭌了兩公斤 
不再失眠, 厭食和忩供

皮膚懂得飲水

思源 明白愛慕自己

可以去除瑠紋和暗瘡

讓陽光帶來小鳥的歌唱

3. 5.2002

\section{Fashioning Passion}

An attractive and well-dressed salesperson

Wearing a trending big hot fuchsia smile

Confided to me,

"It will turn chilly next week!"

Seizing two bags of clothes and a pair of shoes from him

I truly believe that

This beloved boutique acts as a city in its unsettled climate

Where one seeks solace in one's own indulgence

The smog buildup

Casts a veiled vision over Victoria Harbor

The black cat cloaked with a layer of gray dust

The tangerine velvet stained with a lavender foam

Coupled with harlequin-colored sprinkled beads of love

The color-blinded confusion ignited the unimaginable sense of softness and glow

Upon prehension the arms be sheltered for warmth

Wrapped in the checkered scarf

That should be no longer than five feet

Don't burden the shoulders!

Enshrouded in seven feet of love

Is an unbearable fashion for the wounded neck 
Graciously, spring and summer pass

Autumn also withers with no expected surprise

Winter too is safe and sound

Without just cause

Would not stir any lingering thoughts for you or him

But like Amelie, the angel whimsically fancies a spectacle

In the nostalgia for trend retro, we realize

No fashion could be outdated

But our act of forgetting only amplifies the awareness

Caught between the dolman sleeve and the A-line skirt

We can only accede that our complexion be, as fated,

Folded, flattened into strips or grids

For clothes are to be worn and

Nowhere else to be

Not until heaven and earth meet at the horizon

Can I be separated from you

1. 5.2015

衣戀

長得整齊好看的售貨員

用這一季大熱的桃紅色的笑容

跟我說:

下星期天氣轉涼了!

從他手上接過兩袋衣物及一雙鞋子

我真情地相信

窩心的服裝店是陰晴不定的城市

最使人沉溺的歸宿處

近日發生煙霞 
維港拉起視線的障礙

黑色的貓蒙上灰色的塵

橘紅的絲絨漂染粉紫的泡沫

就連藏青的愛情也斑斑點點

色盲的錯亂使我前所未有的溫柔和明豔

終於也覺醒保護容易著涼的手臂

便要披上千鳥格子的圍巾

圍巾的長度最好不要超過五尺

別叫肩膊太沉重啊!

七尺昂藏的情愛

是受傷的後頸所無法承受的時尚

輕質化地渡過春天和夏天

秋天亦無驚無險期望

冬天也出入平安不會無緣無故

搞起對你或對他的思前想後

但愛美麗的天使總喜歡肆意地華貴

懷舊的時裝潮流裡我們必須面對

沒有一套流行款式會已成過去

我們對彼此的遺忘祗會不斷重覆的辨認

於是在A-Line短裙與蝙蝠衣袖的去而復返間

我們祗好宿命地將彼此的容顏

摺成扁扁平平的橫紋與格線

因為衣服都穿在身上不留別處

直到天地合

乃敢與君絕

8. 11.2003 


\section{The Lover, My Clothes}

What if there're two summer seasons

So that the fixed deposit of love has a longer maturity

What if lovers are just my clothes

So that I can change the way I miss them like the latest fashion

March mist with spring rain, putting

A bohemian embroidered blouse on me,

Weaves two separate cities with the thread of my cuff

But leaves a gap in the shape of the rugged edge of the stamp.

April, with the cruelest sun, has an overcast face,

Flanked by showers and rainbows, which matches with an amethyst butterfly knot

Animating an aura, a frequency of the heartbeat

That could hold your hand as you jay-walk just in time,

Fill it with an inviolable force.

Stars pinch holes on the sky of May

As I sprinkle delicate glittering lip gloss

And tint slithering eyebrows, shining under the streetlights

My shadows at evenings striding behind your eyes.

And then so goes June, and then August,

Let's not mention July when we go sour.

Time to lay out-of-season clothes in peace

To sort them out and bid farewell

Your mind is obscure behind the see-through chiffon dress

While my tassels on the jean become a burdening mess

No paisley prints blow away the green ending of a relationship

The folk embroidered weaves an ageless story too good to be true

Clothes and people, once in, now out,

Drag on a shadow from this year that

Won't get you admitted to the next fashion show

Turns out it's not as hard as commonly believed

To throw away old clothes or get carried away by fashion

Lovers are my clothes 
Close is my tight hugging skirt, but closer is my cool skin And sweat stains.

And gossips run about

How the dress doesn't flatter you!

If I had two summers

I'd give love a re-boot

Because how easily it slips off your memory

That July is my birthday

While a grey scarf once slipped into your wardrobe

Some day in winter on your birthday.

Translated by Wayne Yeung

2015

\section{愛人. 衣服}

期待有兩個夏季

可以延長愛情的定期儲蓄

期待愛人如衣服

隨每天的潮流更新想念的姿態

三月的霧和雨連成一線

特意披一件波希米亞的通花上衣

讓袖口的絲縫起兩座城市的間隙

剪成郵票錯體相連的齒痕

四月的太陽有一張陰陽的臉

驟雨中的彩虹配一條紫水晶的蝴蝶結

讓磁場拍和心跳的振率

相信及時拉住你亂闖馬路的手

有恆久拍翼的能量

五月的夜有星星洞穿了的天

小心翼翼塗上閃金的唇彩 
描出蛇的眉額在街燈的映照下 你的眼睛印下我的影子

然後六月和八月都過去了

吵罵的七月給我們遺失或遺忘

是時候把過時的衣服好好殮藏

分門別類再分道揚鐎

see through 的雪紡仍看不透你去留的心思

牛仔褲的流蘇拉得太長變成紏纘的負累

田園的印花吹不開一個愛情綠色的結局

刺紼的民族圖案不過是騙人的不老傳說

去年流行的服飾今年已成舊人

今年緊緊抱住的身影無法過渡

明年春季的花生騷

原來抛棄一件衣服或給潮流电掉

並不如想像中困難

原來愛人如衣服

曾經緊貼然後冷卻是體溫

因汗漬而斑駁

別人還會說三道四

說衫長褲短衣不稱身呢

如果我有兩個夏季

會重新選擇愛情的起點

因為七月是我出生的日子

而你總會刻意忘記

其實某年冬天你生日的時候

曾偷偷給你放下一條灰領巾

1. 5.2002 


\section{Poetic Entry on Mongkok}

1. Shun Wo Centre (take two)

Entranced into the Japanese soap opera disc market, entranced into The Love Generation's Long Vacation

Pressed between bodies trudging to and fro,

In cramped narrow alleyways with no fire escape

In search of a lost smile

That has been for a time abandoned on the roadside

Piano notes float timidly around the corner

Played gently by hesitant fingers, youth is

The will to stay in the hollowed chamber in solitude

Would you still hang around

The empty shot imbued with furniture leaves a heavy anxiety from within and without the frame

I take a step forward to avoid the restless crowd behind

To almost be compressed onto the TV screen

When the eyes of the protagonist leaned close to my face

I stole a glance at our resemblance and in an instant

Again that glamour, that suspense, and that passion have been felled and stepped on by

A large retinue of foot prints

Flattened into illegal pirated CD-ROMs

2. Sin Tat Plaza (take one)

Like a working camera

At the speed of light you

Dolly around the cramped space between the pressed bodies

Kindachi, Black Jack, the

Childish Kimura Takuya and

Matsu Takako who shrugs with delight

Whose smile would you like to capture

On your face

Following your light speed in the flying pose of Ultraman

I forebode 
To become the black speck of the universe

For the exit door is occluded by the projected light from the TV screen

Our relationship has reached an impasse; regrets no more

At the season finale you still have not informed me

Whether there'll be a sequel?

\section{Shun Wo Centre (flash back)}

The criss-crossed escalators scattered with scrap papers

Akin to a pair of time tunnels in chiasmus

I return from the Long Vacation of Love Generation

Bringing the film reels of memory in reverse time-space

And seeking the possibilities suggested by the characters and plots

You're on my mind

Through the reflected glass pillars behind,

The two different TV screens play the same scene in unison

Where the game show host exerts much effort in his performance

From comic depictions of melodramatic suffering shown by dipping his hand in boiling water

To puckering the rounded mouth into

A triangular-shaped kiss on the camera lens

I gaze at the bounding bodies on the screen, devoid of any desire to laugh only

The swift neon lights flit past like the Taipei high-speed rail on heartbeating axels;

Slowly frozen into a pale white face

Having been away from the city

The Japanese soap operas have changed their subject

In the multitude of visual images we can only grasp

The fleeting color and sounds

Only memory and imagination represent the present

Creeping beyond the edges of the city

Setting aside the promises made in history

We will then not only brush pass

1. 12.2014 


\section{詩錄旺角}

1. 信和中心 (take two)

走進日劇的光碟市場走進

戀愛世代的悠長假期

身體與身體擠壓的空間沒有

走火防火的通道上來來回回

尋找被時間遺棄於路旁

一個掉在過去的笑容

轉角有羞郝的琴聲滑動

猶豫的指頭青春原來是

獨自坐在虛空的房子內的意志

Would you still hang around

佈滿傢俱的空鏡凝聚鏡內鏡外

等待的焦慮

我挪前一步避去人群站在後面的急躁差點便給擠進了電視的熒

幕董

當主角的眼睛湊近我的臉龐時

竟瞥見你我的類像 刹那

瀟灑滿地驚疑的喜怒哀樂

再給前呼後擁的鞋印踩成

不合規格的翻版光碟

2. 先達廣場 (take one)

像啟動的攝影機 
你以光的速度游行於

一堆身體互相擠壓推撞的空隙之間

金田一、怪醫秦博士還有

永遠孩子氣的木村拓哉與常常

喜歡篮肩的松隆子

你願意把誰的笑容攝入

自己的臉上

追隨你的光速像吉田超人飛行的姿勢我害怕

終會變成宇宙的黑點因為

逃生的前門已被熒光屏的激光堵住

我們的關係便必須因為後無退路而義無反顧

但當連續劇結束的時候你還沒有

告訴我有沒有續集的可能?

3. 信和中心 (flash back)

佈滿廢紙的自動電梯上下移動

像穿過兩條方向相反的時光隧道

我從戀愛世代的悠長假期中回來

帶着回憶的膠卷在倒轉的空間裏

尋找人物與情節兌現的可能

you're on my mind

反光的玻璃柱上我看見身後

兩個不同的熒光屏放着相同的畫面

遊戲節目的主持人賣力地演出

各種滑稽的動作例如把手掌掉到

鍋裏煮湯再用驚呼的表情

把圓形的嘴巴拉成 
三角的圖案然後吻在鏡頭上

我緊緊盯着銀幕上跳動的肢體卻沒有發笑的衝動 祇有

台北高速滑動的虹影在心跳的軸輪上漸漸凝住一張臉孔的黑白

離開這城市一段日子

日劇的熱賣已改變了內容

光影的世代裏我們往往祇能抓住

一些多多的顏色和聲音

祇有記憶和想像才是現世的

爬過城市的邊緣

电掉歷史的承諾

我們才不會擦身而過

5. 1998

\section{Traversing between the New Year's Eve and the New Year's Day in 2003}

I put on the apparel of time

Allowing its sleeves to outgrow my arms

I leave time in my dress

Allowing its visage to outlive the vogue

Ever since winter time

The thermometer is changing faces all the time

My heart expands and contracts

Following the rising and falling notes of the Christmas carols

I turn to the last page of the calendar

Does tearing off the page of debt bring about a better year?

On the New Year's Eve the cancer-stricken singer

Finishes her terminal journey

In this new, festive beginning

I am caught by total surprise 
The air-conditioner in the shopping mall is raised an octave higher The freezing invisible air solidifies an icy visible landscape A polar bear shakes its head on a man-made snow scene Announcing the possibility of the revival of a dead city One day in the middle of the shopping mall An imposing Christmas tree reaches the fourth floor Its green plastic or silky leaves Are perfect matches with the glittering, white crystals Deck the tree with names of commercial sponsors And the white labels of the paper swan cutouts Seeing the intertwined branches and twinkles under the spotlight She starts to believe

She has already been free from the tragic fate of an ugly duckling Transformed into a swan

Desiring flight

But the illusory lights weigh her down

All the way to the far end of the staircase

Treading on the layers and layers of the escalators

Starting from the lowest level

Our every step is an upward bound

Looking up to the glass roof on the top floor

Stars, moons, suns are within reach

With a closer look

She discovers the patterns of laser projections

Carol and hymn singing comes from afar, sublime and sweet

She has nothing but only an oversized coat

New year wishes can be rich and light

As light as the upward balloon and the moon

Wind is blowing from the corner of the staircase

Between last year and the next

She has put on her overcoat again

Allowing time to be thinner than her clothing

Allowing her apparel to outlive time

Translated by Esther M. K. Cheung

15. 1. 2013 


\section{走過除夕與元旦的交界2003}

將歲月披在身上

讓它的衣袖比手臂長

將衣裳留在歲月裡

讓它的容顏比潮流恆久

\section{入冬以後}

溫度計時刻反臉無常

冷縮熱脹的心情

隨著聖誕的歌聲浮浮沉沉

把日曆紙翻到盡頭

撕下舊賬是否真的可以新年進步?

除夕之前患癌病的歌手

趕上她最後的旅程

原來「從頭開始」的時節

是這樣令人措手不及

把空調昇到第八音節的購物中心

讓隱形的空氣凝結可見的冰天雪地

人造的雪景和會搖頭的北極熊

告訴沉溺死亡的城市再生的可能

商場的中央從某天開始

复立了一座四層高的聖誕樹

塑膠或絲絹的綠松葉

配䘽會發亮閃光的白水晶

樹上高高掛著贊助商的名字

以及天鵝剪影的白色商標 
抬頭仰視射燈下縱橫錯亂的枝葉與閃光

她從此相信

自己也是一隻天鵝

早已脫離醜小鴨的磨難

渴望飛 但燈光的幻影使她沉淪不起

直到樓梯盡頭

走過重重疊疊的自動升降機

從底層開始

每一步都是上昇

仰望頂樓玻璃的天幕

星星、月亮和太陽彷彿垂手可得

但走近了才知道

原來那是激光投映的圖案

遠處傳來雄壯愉悅的歌詠和聖詩

面前祗有兩手空空抱住一件oversize的大衣

原來新年的祝願可以如此飽滿和輕盈

輕得如昇空的汽球或月球

樓梯的彎角有風

在來年與去年之間

她重新披上大衣

讓歲月比衣裳薄

衣裳比歲月長

1. 1.2004 


\section{References}

Benjamin, Walter. 2007[1968]. Illuminations. New York: Schocken Books. 1986 [1978]. Reflections. New York: Schocken Books.

Bennett, Jane. 2001. The Enchantment of Modern Life. Princeton and Oxford: Princeton University Press.

Bertelsen, Lone and Murphie, Andrew. 2010. An Ethics of Everyday Infinities and Powers. In The Affect Theory Reader, Ed. M. Gregg and G. Seigworth, 138-157. Durham and London: Duke University Press.

Chan, Natalia Siu-hung (Lok Fung). 1995. Introduction. In The Decadent City ( 世紀末城市), 1-7. Hong Kong: Oxford University Press.

. 2002. Introduction. In City on the Edge of Time (香港電影的性別、特 技與九七政治), 1-8. Hong Kong: Oxford University Press.

. 2007. Arabesque (阿拉貝斯克舞步). In The Flying Coffin (飛天棺材), xxxv-xlv. Hong Kong: Wheatear Publishing Company Limited. . 2007. The Flying Coffin (飛天棺材). Hong Kong: Wheatear Publishing Company Limited.

Cheung, M K Esther. 2004. Cinema and the City at a Moment of Danger. In Between Home and World, Ed. E M K Cheung and Y. W. Chu, 248-271. Hong Kong: Oxford University Press.

. 2012a. The Ordinary Fashion Show: Eileen Chang's Profane Illumination and Mnemonic Art. In Eileen Chang: Romancing Languages, Cultures and Genres, Ed. K Louie, 73-90. Hong Kong: Hong Kong University Press. . 2012b. The Poetics of Dislocation in Natalia Chan's Poetry. (Paper presented at 2012 Annual Meeting of American Comparative Literature Association, Brown University, Providence, Rhode Island, U.S.A, March 29 to April 1).

Chow, Rey. 1993. Things, common/places, passages of the port city: on Hong Kong and Hong Kong author Leung Ping-kwan. differences: A Journal of Feminist Cultural Studies 5.3:179-204.

De Man, Paul. 2013. Blindness and Insight. $2^{\text {nd }}$ Edition. Oxon: Routledge.

Deleuze, Gilles and Guattari, Félix. 1986. Kafka: Toward a Minor Literature. Translated by Dana Polan. Minneapolis and London: University of Minnesota Press.

Entwistle, Joanne. 2015. The Fashioned Body. $2^{\text {nd }}$ Edition. Cambridge: Polity Press. 
Giddens, Anthony. 1990. The Consequences of Modernity. Cambridge: Polity Press.

Gordon, Avery F. 1997. Ghostly Matters. Minneapolis and London: University of Minnesota Press.

Gregg, Melissa \& Seigworth, Gregory J. Ed. 2010. The Affect Theory Reader. Durham and London: Duke University Press.

Harootunian, Harry. 2000. History's Disquiet. New York: Columbia University Press.

Massumi, Brian. 1987. Notes on the Translation and Acknowledgements. In $A$ Thousand Plateaus: Capitalism and Schizophrenia. G. Deleuze and F. Guattari. Translated by Brian Massumi, xvi-xix. Minneapolis and London: University of Minnesota Press.

Paetzold, Heinz. 1987. The Philosophical Notion of the City. In The City Cultures Reader, Ed. by M. Miles, T. Hall, and I. Borden, 204-220. London and New York: Routledge.

\section{Notes}

1. All translations are mine unless stated otherwise.

2. Deleuze and Guattari, in their discussion of Kafka's literature, maintain that "minor literature" can be identified by three features: deterritorialization, an emphasis on politics, and collective value (1986, 16-27). Their extensive discussion of Kafka's work may not be directly related to Chan's case, but it sheds light on the function of the minor mode-the writing of the marginalized-in the reflection of larger historical and cultural contexts.

3. Both Long Vacation and Love Generation are Japanese TV series that were immensely popular in Hong Kong in the late 1980s. The names of these series are given in English in the poem.

4. The phrase "you're on my mind" is written in English in the poem. 